\title{
PERTUMBUHAN BIJI TERATAI (Nymphaea pubescens WILLD.) PADA KONDISI ASAM DAN LAMANYA PENCAHAYAAN ALAMI
}

\author{
(Growth Of Lotus Seeds (Nymphaea pubescens Willd.) In Acid Conditions And The Duration Of \\ Natural Lighting)
}

B.N. Ismuhajaroh dan C. Nisa

Fakultas Pertanian Universitas Lambung Mangkurat J1. Ahmad Yani Km 33 Banjarbaru email : nisa_unlam@yahoo.co.id

Article Submitted : 22-10-2019

Article Accepted : 05-02-2020

\begin{abstract}
Lotus is a water plant that thrives in the swamp waters of South Kalimantan. These plants in some areas are rapidly decreasing due to expansion, urbanization, industrialization, and other land uses that affect their habitat. The germination and growth of lotus seeds is very dependent on the state of the surrounding environment, especially the level of acidity and lighting from sunlight. This study aims to determine the effect of acidity and duration of natural lighting on the growth of lotus seeds. The study was conducted at the Laboratory of Agricultural Biology, Faculty of Agriculture ULM in March to June 2016. The design used was a Separate Plot Design in a Randomized Block Design, as the main plot was the acidity level of water consisting of 11 levels and as a subplot was the lighting duration consisting of of 5 levels with two replications. The results showed that lotus seeds can grow from media which have a acidity level $(\mathrm{pH}) 3-3.5$ and a base $\mathrm{pH}$ of 7.5-8. Seeds can germinate and grow in both dark and bright conditions, but treatment with a long exposure time of 7 and 24 hours of light is the best.
\end{abstract}

Keywords: acidity, lighting, germination, growth, lotus

\section{PENDAHULUAN}

Teratai termasuk dalam genus Nymphaea dan merupakan keluarga Nymphaeaceae terdapat sekitar 50 spesies (Selvakumari et al., 2012; Zhu et al., 2012; Mendez dan Miranda, 2015) terdiri dari dua kelompok besar yaitu Apocarpiae dan Syncarpiae berdasarkan perpaduan dinding carpel (Conard, 1905). Seluruh spesies tersebar luas di daerah tropis dan meluas ke daerah beriklim sedang menempati air tawar, kolam, danau yang dangkal, sungai yang mengalir lambat, dan rawa (Swingle, 1959; Guruge et al., 2016). Hampir semua Nymphaeae merupakan perenial aquatic (Conard, 1905; Sumlu et al., 2010) yang dapat berkembangbiak dengan menggunakan umbi, stolon, dan biji (Biwas dan Rahmatullah, 2011; Wiersema, 1987).
Teratai merupakan tumbuhan multi fungsi, baik sebagai tanaman hias, pengobatan tradisional (Aliyu, 2017; Roy, et al., 2013), sumber pangan yang bernilai tinggi (Issac, 1987; Roy, et al., 2013; Deka dan Devi, 1915), dan untuk upacara keagamaan (Conard, 1905). Keindahan bunganya dapat digunakan sebagai ornamen dalam taman air dan banyak dikembangkan sebagai tanaman hortikultura (Anonim, 2008; Begum, et al., 2010). Komponen fitokimia yang terdapat pada ekstrak biji teratai mengandung: alkaloid, tannin, saponin, glikosida, flavanoid dan triteerpenoid, sedangkan ekstrak umbi mengandung: alkaloid, tannin, saponin, glikosida dan steroid sehingga menurut Fitrial (2008) biji dan umbi memiliki aktivitas antibakteri yang berpotensi sebagai 
antibakteri dan probiotik. Bagian rhizome mengandung phenolics, flavonoids yang digunakan sebagai antioksidan (Fitrial, 2008; Daffadil dan Mohan, 2013). Anthocyanin pada warna bunga berperan penting dalam bioaktivitas termasuk antioksidan, antikangker (Zhu et al., 2012; Selvakumari et al., 2012), antidiabetic (Katriyayini, et al., 2011; Hemalatha dan Lavarasan, 2016), dan antihepatotoxic (Muthulingam, 2011). Semua bagian tumbuhan teratai dikonsumsi pada saat terjadi kelangkaan pangan untuk memenuhi kebutuhan gizi keluarga (Biswas dan Rahmatullah, 2011) sebagai sayuran dan makanan (Jain 1991; Mohan et al., 2010). Biji teratai merupakan sumber karbohidarat $(88,36 \% \mathrm{BK})$. protein $(10,39 \% \mathrm{BK})$, asam amino esensial lengkap dengan kadar lemak rendah $(0,58 \%)$, dan serat $(7,9 \%)$. Kualitas gizi yang tinggi dapat memerangi penyakit yang terkait dengan kekurangan gizi serta dapat direkomendasikan untuk makanan anak-anak, karena kandungan arginine dan histidin (Aliyu, 2017). Berbagai manfaat ini bukan tidak mungkin masyarakat akan mengekploitasi. Masyarakat hanya memungut saja hasil tanpa membudidayakan. Menurut Kusumo et al. (2002) Dalam Krismawati dan Sabran (2003), beberapa plasma nutfah menjadi rawan dan langka bahkan punah karena terjadi kondisi sumber daya hayati, lahan, dan habitat akibat pemanfaatan yang tidak terkendali.

Pengembangbiakan tanaman perlu dilakukan sebagai tindakan dalam konservasi sumberdaya (Rahangdale dan Rahangdale, 2013). Ancaman kepunahan pada species Nymphae sangat memungkinkan, menurut Dalziell (2016) species Nymphaea menunjukkan hidup yang pendek dalam penyimpanan ketika dibandingkan dengan spesies lainnya. Menurut Bodhipadma et al., (2011) tanaman ini di beberapa daerah cepat berkurang karena ekspansi, urbanisasi, industrialisasi, dan penggunaan lahan lainnya yang mempengaruhi habitatnya. Berdasarkan tempat tubuhnya, lahan rawa mempunyai potensi yang besar untuk pengembangan teratai. Propinsi Kalimantan Selatan memiliki lahan rawa yang cukup luas, menurut Fitrial dan Khairina, (2011) lahan rawa yang biasa ditumbuhi teratai adalah rawa lebak. Sentra produksi biji teratai di Kalimantan Selatan berada di kabupaten Tabalong, Hulu Sungai Utara dan Hulu Sungai Tengah. Pada tahun 2012 ketiga daerah tersebut mempunyai luas lahan penghasil biji teratai masing-masing 10.683 ha, 21.225,2 ha dan 18.763 ha dengan produksi setiap wilayah berpotensi menghasilkan biji teratai sebanyak $11.976,661 \quad \mathrm{t} / \mathrm{ha} ; \quad 224.456,2 \quad \mathrm{t} / \mathrm{ha}$ dan 12.254,6778 t/ha (Khairina dan Rusmayadi, 2012). Masyarakat di tiga daerah tersebut tidak melakukan pembudidayaan teratai, mereka hanya memungut biji teratai yang tumbuh liar pada musim hujan, sedangkan pada musim kemarau lahan persawahan digunakan untuk menanam padi (Fitrial dan Khairina, 2011). Metode yang efisien untuk melestarikan dan meningkatkan jumlah serta mengurangi hilangnya tanaman dari alam adalah dengan cara membudidayakannya.

Perkecambahan dan pertumbuhan biji teratai sangat tergantung pada keadaan lingkungan sekitarnya terutama tingkat keasaman dan pencahayaan dari sinar matahari. Penelitian ini bertujuan untuk mengetahui pengaruh tingkat keasaman dan lama pencahayaan alami terhadap pertumbuhan biji teratai.

\section{METODE PENELITIAN}

Penelitian dilaksanakan di Laboratorium Biologi Pertanian Fakultas Pertanian Universitas Lambung Mangkurat (ULM) mulai bulan Maret-Juni 2016. Rancangan yang digunakan adalah Rancangan Petak Terpisah dalam Rancangan Acak Kelompok. Sebagai petak utama adalah tingkat keasaman air $(\mathrm{pH})$ yang terdiri dari 11 taraf $(\mathrm{pH} \mathrm{3;} \mathrm{pH} \mathrm{3,5;} \mathrm{pH} 4 ; \mathrm{pH}$ 4,5; $\mathrm{pH} 5 ; \mathrm{pH} \mathrm{5,5;} \mathrm{pH} 6$; $\mathrm{pH} 6,5 ; \mathrm{pH} 7 ; \mathrm{pH}$ 
7,5; dan $\mathrm{pH}$ 8), dan sebagai anak petak adalah lama penyinaran matahari yang terdiri dari 5 taraf ( 24 jam gelap, 7 jam terang, 8 jam terang, 9 jam terang, dan 24 jam terang). Masing-masing perlakuan diulang 2 kali, menghasilkan 110 satuan percobaan, setiap satuan percobaan menggunakan 20 butir benih. Analisis data menggunakan Statistical Tool for Agricultural Research (STAR) dengan uji BNT pada taraf 5\%. berikut:

Tahapan penelitian adalah seperti

1. Persiapan, yaitu mengumpulkan buah teratai yang telah tua, kemudian didiamkan selama satu malam atau ditunggu hingga buahnya pecah. Ambil biji dan pisahkan dari kulit buahnya kemudian dicuci dengan air mengalir hingga bersih atau sampai kulit ari yang menempel pada biji hilang. Biji diratakan di atas kertas koran dan dikeringanginkan selama tiga hari. Pilih biji dengan ukuran yang sama dan hitung sejumlah perlakuan

2. Perlakuan keasaman pada $\mathrm{pH}$ dibawah 6 menggunakan $\mathrm{HCl} 1 \mathrm{~N}$ (normalitas) dan diatas 6 menggunakan $\mathrm{KOH} \quad 1 \quad \mathrm{~N}$. Larutan dibuat sedemikian rupa sehingga $\mathrm{pH}$ sesuai yang diinginkan. Nilai $\mathrm{pH}$ dalam proses pertumbuhannya dikontrol dengan $\mathrm{pH}-\mathrm{Meter}$

3. Perlakuan cahaya memerlukan penutup untuk membuat kondisi dengan lama pencahayaan yang berbeda. Penutup yang digunakan dibuat dari tudung saji yang dilapisi dengan aluminium foil sampai rapat atau cahaya matahari tidak dapat masuk. Penutup tersebut dapat digunakan untuk mengatur lama pencahayaan oleh sinar matahari atau dengan system buka tutup. Perlakuan lama pencahayaan dengan sinar matahari semua perlakuan murni dengan pengaturan lama pencahayaan dengan tutup, namun pada perlakuan lama pencahayaan selama 24 jam disambung dengan cahaya lampu TL

4. Penanaman dilakukan dengan meletakkan biji pada petridisk yang telah dialasi dengan kertas saring basah. Masing-masing petridisk di isi 20 biji dan sesuai perlakuan

5. Pemeliharaan dilakukan dengan menambahkan air dengan pipet sesuai masing-masing perlakuan keasaman. Penambahan dilakuan setiap tiga hari sekali atau sesuai kebutuhan

6. Pengamatan dilakukan dengan mengamati daya berkecambah (DB,\%), keserempakan tumbuh ( $\left.\mathrm{K}_{\mathrm{ST}}, \%\right)$, kecepatan tumbuh $\left(\mathrm{K}_{\mathrm{CT}}\right.$, \%), panjang sulur $(\mathrm{cm})$, panjang plumula $(\mathrm{cm})$ dan panjang radikula $(\mathrm{cm})$.

Menurut Sutopo (1998), persentase perkecambahan dapat dihitung dengan rumus sebagai berikut:

Daya berkecambah (DB, \%). Dihitung berdasarkan persentase kecambah normal (KN) hitungan pertama (12 Hari Setelah Tanam) dan kedua/terakhir (14 HST) dengan rumus:

$$
\mathrm{DB}=\frac{(\Sigma \mathrm{KN} \text { hitungan } \mathrm{I}+\Sigma \mathrm{KN} \text { hitungan II })}{\Sigma \text { benih yang ditanam }} \times 100 \%
$$

Keserempakan tumbuh $\left(\mathrm{K}_{\mathrm{ST}}\right)$ dihitung berdasarkan persentase KN pada 13 HST, Kecepatan tumbuh $\left(\mathrm{K}_{\mathrm{CT}}\right)$ dihitung berdasarkan total tumbuh $\mathrm{KN}$ setiap hari (interval 24 jam) hingga pengamatan kecambah hitungan kedua/akhir (14 HST) dengan rumus: 
Keterangan:

$$
\mathrm{K}_{\mathrm{CT}}={\underset{0}{\operatorname{tn}} d}_{0}^{\mathrm{T}} \frac{\mathrm{N}}{\mathrm{T}}
$$

$\mathrm{t}=$ hari pengamatan, $\mathrm{tn}=$ waktu akhir pengamatan,

$\mathrm{N}=$ persentase pertumbuhan kecambah normal setiap waktu pengamatan

\section{HASIL DAN PEMBAHASAN}

Perkecambahan adalah munculnya radikula diikuti pemanjangan hipokotil secara keseluruhan dan membawa serta kotiledon dan plumula ke atas permukaan (Sutopo, 1998). Ada beberapa hal yang menyebabkan proses perkecambahan tidak terjadi sehingga biji mengalami dormansi. Menurut Baskin dan Baskin (2014) dormansi fisiologi biji pada spesies yang hidup di air termasuk kelas predominan dormansi. Spesies tanaman air dalam pemecahan dormansi memerlukan kondisi yang sesuai, sehingga biji dapat memecahkan dormansinya. Menurut Cronk dan Fennessy (2001), perkecambahan biji baik tumbuhan di darat maupun air keduanya memerlukan temperatur yang optimal, cahaya, oxygen, air untuk tumbuh.

\section{Keasaman (pH)}

Keasaman atau $\mathrm{pH}$ air merupakan faktor penting dalam proses perkecambahan tumbuhan air. Menurut Deska et al. (2011) ada banyak spesies tumbuhan memiliki persyaratan fisiologis yang sangat spesifik mengenai keasaman. Demikian juga pertumbuhan teratai yang memiliki pertumbuhan sangat spesifik terhadap $\mathrm{pH}$ air, dari hasil penelitian menunjukkan bahwa biji dapat berkecambah dan tumbuh pada tingkat keasaman $(\mathrm{pH} 3)$ maupun basa $(\mathrm{pH}$ 8) (Tabel 1).
Daya berkecambah teratai pada $\mathrm{pH} 3$ dan $\mathrm{pH} 8$ adalah yang paling rendah masingmasing $1,61 \%$ dan $1,35 \%$, namun tidak berbeda nyata dengan tingkat keasaman terendah sampai tertinggi (basa). Hal demikian sama dengan keserempakan tumbuh, kecepatan tumbuh, panjang sulur, dan panjang plumula. Terlihat bahwa pada air aquades yang merupakan kontrol $(\mathrm{pH}$ 5,7 ) justru menunjukkan pertumbuhan yang tertinggi pada parameter daya berkecambah, keserempakan tumbuh, kecepatan tumbuh, panjang sulur, dan panjang plumula, namun tidak berbeda nyata pada $\mathrm{pH} 3-\mathrm{pH} 7,5$. Hal ini menunjukkan bahwa teratai dapat berkecambah dan tumbuh dari $\mathrm{pH}$ yang ekstrim rendah sampai $\mathrm{pH}$ yang dalam kondisi basa.. Kemampuan teratai tumbuh pada kondisi yang demikian menunjukkan bahwa proses perkecambahan dan pertumbuhan biji mempunyai toleransi yang sangat tinggi terhadap baik pada tingkat keasaman rendah sampai pada kondisi basa. Menurut Fitria (2011) Dalam Nugroho (2011), pengaruh derajat keasaman akan menentukan mudah tidaknya unsur hara diserap oleh tanaman, pada $\mathrm{pH}$ yang optimum proses perkecambahan biji dapat berlangsung lebih cepat. Menurut Webb et al. (2012) penyerapan $\mathrm{CO}_{2}$ dalam air lambat dibandingkan dengan yang ada di atmosfer dan kecepatan $\mathrm{CO}_{2}$ dapat berkurang dalam air akibat $\mathrm{pH}$ yang tinggi, namun teratai dapat berkecambah dengan baik. Jelas bahwa dengan toleransi yang tinggi memungkinkan sekali teratai tumbuh di lahan rawa pasang surut dan lahan rawa gambut sebagai tempat habitatnya (Fitrial dan Khairina, 2011). 
Tabel 1. Rata-rata pengaruh berbagai perlakuan keasaman terhadap daya berkecambah (DB), keserempakan tumbuh (KST), Kecepatan tumbuh (KCT), Panjang sulur, dan Panjang plumula

\begin{tabular}{|c|c|c|c|c|c|c|c|}
\hline \multirow{2}{*}{$\begin{array}{l}\text { Tingkat } \\
\text { Keasaman Media } \\
\text { Tanam }(p H)\end{array}$} & \multirow[t]{2}{*}{ DB $(\%)$} & \multirow[t]{2}{*}{$\begin{array}{l}\mathrm{KST} \\
(\%)\end{array}$} & \multirow[t]{2}{*}{$\begin{array}{c}\mathrm{KCT} \\
\left(\% \text { etmal }^{-1}\right)\end{array}$} & \multicolumn{2}{|c|}{$\begin{array}{l}\text { Panjang Sulur } \\
(\mathrm{cm})\end{array}$} & \multicolumn{2}{|c|}{ Panjang Plumula $(\mathrm{cm})$} \\
\hline & & & & $3 \mathrm{mst}$ & $5 \mathrm{mst}$ & $3 \mathrm{mst}$ & $5 \mathrm{mst}$ \\
\hline $\begin{array}{l}\text { Air Aquades } \\
(\mathrm{pH} 5,7)\end{array}$ & $4,35 \mathrm{a}$ & $2,86 a$ & $1,36 \mathrm{a}$ & $2,48 \mathrm{a}$ & $2,52 \mathrm{a}$ & $1,96 a$ & $2,06 a$ \\
\hline $\mathrm{pH} \mathrm{3,0}$ & $1,61 b$ & $1,51 \mathrm{ab}$ & $0,87 a b$ & $1,02 b$ & $1,04 b$ & $0,97 \mathrm{ab}$ & $0,97 a b$ \\
\hline $\mathrm{pH} \mathrm{3,5}$ & $2,43 a b$ & $2,10 \mathrm{ab}$ & $1,04 a b$ & $1,54 \mathrm{ab}$ & $1,58 b$ & $1,35 \mathrm{ab}$ & $1,41 \mathrm{ab}$ \\
\hline $\mathrm{pH} 4,0$ & $2,58 \mathrm{ab}$ & $1,88 \mathrm{ab}$ & $1,07 \mathrm{ab}$ & $1,33 b$ & $1,55 \mathrm{~b}$ & $1,13 \mathrm{ab}$ & $1,38 \mathrm{ab}$ \\
\hline $\mathrm{pH} 4,5$ & $2,07 \mathrm{ab}$ & $1,03 b$ & $0,91 \mathrm{ab}$ & $1,53 b$ & $1,56 b$ & $1,12 \mathrm{ab}$ & $1,40 \mathrm{ab}$ \\
\hline $\mathrm{pH} \mathrm{5,0}$ & $2,04 \mathrm{ab}$ & $1,03 b$ & $0,92 \mathrm{ab}$ & $1,37 b$ & $1,41 b$ & $1,23 \mathrm{ab}$ & $1,29 \mathrm{ab}$ \\
\hline pH 5,5 & $1,23 b$ & $0,96 b$ & $0,79 b$ & $0,95 b$ & $0,95 b$ & $0,81 b$ & $0,88 \mathrm{~b}$ \\
\hline $\mathrm{pH} 6,0$ & $0,87 b$ & $0,71 b$ & $0,72 b$ & $0,71 b$ & $0,71 b$ & $0,71 b$ & $0,71 b$ \\
\hline $\mathrm{pH} 6,5$ & $1,56 b$ & $0,96 b$ & $0,84 b$ & $1,12 b$ & $1,16 b$ & $1,12 \mathrm{ab}$ & $1,13 \mathrm{ab}$ \\
\hline $\mathrm{pH} 7,0$ & $1,92 \mathrm{ab}$ & $1,34 b$ & $0,90 \mathrm{ab}$ & $1,35 b$ & $1,37 b$ & $1,27 \mathrm{ab}$ & $1,30 \mathrm{ab}$ \\
\hline $\mathrm{pH} 7,5$ & $2,34 a b$ & $1,67 \mathrm{ab}$ & $1,01 \mathrm{ab}$ & $1,22 b$ & $1,27 b$ & $1,14 \mathrm{ab}$ & $1,24 a b$ \\
\hline $\mathrm{pH} \mathrm{8,0}$ & $1,35 \mathrm{~b}$ & $1,03 \mathrm{~b}$ & $0,83 b$ & $0,90 \mathrm{~b}$ & $0,93 b$ & $0,84 \mathrm{~b}$ & $0,84 \mathrm{~b}$ \\
\hline
\end{tabular}

Keterangan: Angka yang diikuti huruf yang sama pada kolom yang sama uji BNT tidak berbeda nyata pada taraf nyata 0,05

Lahan rawa pasang surut di Kalimantan Selatan pada umumnya memiliki tingkat keasaman yang tinggi. Menurut Subagyo (2006) daerah rawa gambut mempunyai reaksi tanah bervariasi antara asam ekstrim ( $\mathrm{pH}$ 3,5 atau kurang) sampai sangat asam, dan rata-ratanya 3,9. Tingkat keasaman di lahan rawa lebak pematang berkisar 5,5-7, tengahan 5-7, dalam 5,5-6,5. Kondisi demikian sangat cocok untuk budidaya teratai, karena tanaman ini mempunyai daya adaptasi yang tinggi terhadap lingkungan tumbuh yang asam ekstrim sampai asam sekali. Menurut Kai, et al. (2012) tanah yang sangat asam menyebabkan tumbuhan mengalami keracunan Aluminium dan Mangan serta kekurangan Kalsium dan Magnesium. Perkecambahan dengan kondisi asam ekstrim sampai asam sekali biji teratai tetap dapat berkecambah dan tumbuh normal, hal ini mengindikasikan bahwa biji teratai dapat terhindar dari kondisi keracunan $\mathrm{Al}$ dan $\mathrm{Ma}$ serta kekurangan $\mathrm{Ca}$ dan $\mathrm{Mg}$. Demikian juga dalam kondisi basa biji teratai dapat berkecambah dan tumbuh dengan baik yaitu pada $\mathrm{pH}$ 5,5-8. Menurut Shen-Miller et al. (2002) Dalam Orozco-Obando, et al. (2001) teratai dapat tumbuh subur meskipun $\mathrm{pH}$ basa, tanaman yang tumbuh di tanah $\mathrm{pH}$ rendah tumbuh lebih cepat tetapi tidak membentuk umbi. Pertumbuhan kecambah biji teratai dapat mentolerir lingkungan terlalu basa, pertumbuhan dan ketersediaan dan pengendapan nutrisi. Menurut Kai et al. (2012), pH diatas 7,5 menyebabkan ion besi, mangan, seng, tembaga dan boron kurang tersedia bagi tanaman.

\section{Lama Pencahayaan Alami}

Menurut Copeland dan McDonald (1985) berdasarkan pengaruh cahaya terhadap perkecambahan benih telah lama dikenal. Respon cahaya benih beberapa ratus spesies telah dipelajari untuk menentukan tumbuhan yang perkecambahan dipengaruhi oleh cahaya, kegelapan, atau ketidak pedulian terhadap cahaya. Menurut Tohari, et al., (2018) Persyaratan cahaya bagi perkecambahan biji sangat rumit, tergantung pada umur biji, kadar air biji, suhu, panjang 
hari, dan zat kimiawi tertentu yang mendorong perkecambahan, suatu piqmen di dalam biji, fitokrom yang terlibat dalam mekanisme pengendaliannya.

Pengaruh lama pencahayaan dari sinar matahari dapat dilihat pada Tabel 2. Lama pencahayaan alami atau sinar matahari mempengaruhi daya berkecambah, keserempakan tumbuh, kecepatan tumbuh, panjang sulur, panjang plumula, dan panjang radikula. Benih yang dikecambahkan pada tempat tanpa cahaya atau ditutup secara penuh tetap mampu berkecambah dan tumbuh namun pertumbuhannya lambat. Kondisi ini mirip dengan yang ada di alam, dengan siklusnya bahwa menurut Basak et al. (2015) bunga Nymphaea awalnya mengapung atau muncul $40 \mathrm{~cm}$ pada pedunculus, kemudian masuk ke dalam air berkembang menua dan akhirnya pecah dan biji berkembang dalam air.

Pertumbuhan benih teratai pada lama cahaya 7 jam dan 24 jam lebih baik dibandingkan dengan tanpa cahaya (Tabel 2). Menurut Basto dan Ramirez (2015), perkecambahan sangat dipengaruhi cahaya, kurangnya cahaya akan berdampak negatif pada respon perkecambahan. Selain itu, menentukan tanggapan terhadap panjang gelombang spectrum yang berkontribusi dalam pencapaian laju dan tingginya perkecambahan dengan mudah menerapkan spesifik panjang gelombang yang ditransmisikan cahaya. Menurut Rokaya dan Münzbergová (2012) perkecambahan biji yang diberi cahaya tumbuh lebih baik dibandingkan biji tanpa cahaya atau dalam keadaan gelap. Efek cahaya sangat berinteraksi dengan efek temperatur. Tingkat perkecambahan terendah pada saat biji dalam keadaan gelap dan temperatur rendah. Menurut Kettenring et al. (2006), perkecambahan biji spesies carex di lahan basah menunjukkan bahwa dari delapan spesies hanya dua spesies yang tumbuh dalam keadaan gelap.

Tabel 2. Pengaruh perlakuan lama pencahayaan terhadap daya berkecambah, keserempakan tumbuh, kecepatan tumbuh, panjang sulur, panjang plumula dan panjang radikula

\begin{tabular}{|c|c|c|c|c|c|c|c|c|c|}
\hline \multirow{2}{*}{$\begin{array}{c}\text { Lama } \\
\text { Pencahayaan } \\
\text { Alami }\end{array}$} & \multirow[t]{2}{*}{$\begin{array}{l}\text { DB } \\
(\%)\end{array}$} & \multirow[t]{2}{*}{$\begin{array}{l}\text { KST } \\
(\%)\end{array}$} & \multirow{2}{*}{$\begin{array}{c}\mathrm{KCT} \\
(\% \\
\left.\text { etmal }^{-1}\right)\end{array}$} & \multicolumn{2}{|c|}{$\begin{array}{l}\text { Panjang Sulur } \\
(\mathrm{cm})\end{array}$} & \multicolumn{2}{|c|}{$\begin{array}{c}\text { Panjang } \\
\text { Plumula }(\mathrm{cm})\end{array}$} & \multicolumn{2}{|c|}{$\begin{array}{c}\text { Panjang } \\
\text { Radikula }(\mathrm{cm})\end{array}$} \\
\hline & & & & $3 \mathrm{mst}$ & $5 \mathrm{mst}$ & $3 \mathrm{mst}$ & $5 \mathrm{mst}$ & $3 \mathrm{mst}$ & $5 \mathrm{mst}$ \\
\hline tanpa cahaya & $0,95 b$ & $0,88 b$ & $0,74 b$ & $0,86 b$ & $0,86 \mathrm{~b}$ & $0,74 b$ & $0,76 b$ & $0,82 \mathrm{~b}$ & $1,02 b$ \\
\hline $\begin{array}{l}\text { lama cahaya } 7 \\
\text { jam }\end{array}$ & $3,64 a$ & $2,44 a$ & $1,25 \mathrm{a}$ & $2,14 \mathrm{a}$ & $2,27 \mathrm{a}$ & $1,61 \mathrm{a}$ & $1,98 \mathrm{a}$ & $2,28 \mathrm{a}$ & $2,90 \mathrm{a}$ \\
\hline $\begin{array}{l}\text { lama cahaya } 8 \\
\text { jam }\end{array}$ & $0,87 b$ & $0,87 b$ & $0,74 b$ & $0,74 b$ & $0,74 b$ & $0,78 b$ & $0,78 b$ & $0,81 b$ & $0,81 b$ \\
\hline $\begin{array}{l}\text { lama cahaya } 9 \\
\text { jam }\end{array}$ & $1,07 b$ & $0,84 b$ & $0,76 b$ & $0,89 b$ & $0,89 b$ & $0,85 b$ & $0,85 b$ & $0,89 b$ & $0,90 \mathrm{~b}$ \\
\hline $\begin{array}{l}\text { lama cahaya } 24 \\
\text { jam }\end{array}$ & $3,62 \mathrm{a}$ & $2,09 a$ & $1,19 \mathrm{a}$ & $1,84 \mathrm{a}$ & $1,91 \mathrm{a}$ & $1,71 \mathrm{a}$ & $1,71 \mathrm{a}$ & $2,00 \mathrm{a}$ & $2,31 \mathrm{a}$ \\
\hline
\end{tabular}

Keterangan: Angka yang diikuti huruf yang sama pada kolom yang sama uji BNT tidak berbeda nyata pada taraf nyata 0,05

Perkecambahan dan pertumbuhan benih teratai dalam kondisi tanpa cahaya menunjukkan tidak ada perbedaan signifikan pada daya berkecambah, keserempakan tumbuh, kecepatan tumbuh, panjang sulur, panjang plumula dan panjang radikula terhadap lama cahaya 8 jam dan 9 jam. Perbedaan tersebut dapat disebabkan kondisi benih yang belum matang atau faktor lainnya. Menurut Gutterman, 2000 Dalam Kattenring, (2006) perbedaan murni interspesifik dalam ekologi benih antara 
spesies cenderung memiliki pengaruh terbesar. Hal ini juga memungkinkan bahwa pengaruh kondisi lingkungan selama pematangan pada dormansi benih memainkan peran.

\section{KESIMPULAN}

1. Teratai dapat tumbuh dalam kondisi ekstrim asam ( $\mathrm{pH} 3$ ) sampai kondisi basa ( $\mathrm{pH} \mathrm{8),} \mathrm{namun} \mathrm{perkecambahan} \mathrm{dan}$ pertumbuhannya rendah.

2. $\mathrm{pH}$ optimum untuk pertumbuhan perkecambahan adalah $\mathrm{pH}$ 5,7 yaitu terdapat pada $\mathrm{pH}$ air aquades.

3. Biji tertai dapat tumbuh walaupun dalam kondisi tanpa adanya cahaya

4. Pertumbuhan terbaik untuk biji teratai adalah pada lama pencahayaan 7 jam dan 24 jam

\section{DAFTAR PUSTAKA}

Anonim. (2008). Archive.lib.cmu.ac.th/ full/T/2008/biol07owl-ch3.pdf

Aliyu M., M.K. Atiku, N. Abdullahi, A. Zaharaddeen, and A.A. Imam. 2017. Comparative evaluation of nutritional qualities of Nymphaea lotus and Nymphaea pubescens seeds. International Tournal of Biochemistry Research and review. 19(3):1-10.

Basak, S.K.B., M.M. Ali, Md.S. Islam and P.R. Shaha. 2015. Aquatic weeds of Haor Area in Kishoregoj District, Bangladesh: Availability, treats and management approaches. International Journal of Fisheries and Aquatic Studies. 2 (6):151-156

Basto, S. and C. Ramírez. 2015. Effect of Light Quality on Tabebuia rosea (Bigniaceae) Seed Germination. Univ. Sci. Vol 20 (2):191-199.
Baskin, J.M. and C.C. Baskin. (2014). Seed ecology, biogeography, and evalution of dormancy and germination. Second edition edn. Academic Press, Elsevier, USA.

Begum, HA., K.K. Ghosal and T.K. Chattopadhyay. 2010. Comparative morphology and floral biology of three species of the genus Nymphaea from Bangladesh. J. Bot. 39(2):179183.

Biwas, K.R. and M. Rahmatullah. 2011. A Survey of non convensional plants consumed during times of food scarity in three adjoining villages of Narail and Jessore Districts, Bangladesh. American Eurasian Journal of Sustainable Agriculture. 59(1):1-5

Bodhipadma, K., S. Noichinda, P. Wachirabongkath, E. Pukpoomin, L. Punnakantan, and K. Nathalang. 2011a. Nymhaea nouchali var. Versicolor 'Bua Phuean': Seed Morphology and Germination in Vitro. Environment and Resources J. Vol 9, No.2 August 2011: 19-25

Bodhipadma, K., S. Noichinda, P. Wachirabongkath, E. Pukpoomin, L. Punnakantan, and K. Nathalang. 2011b. In vitro Propagation of Nymphaea nouchali var. Versicolor 'Bua Phuean' The Journal of Apllied Science. Vol. 10. No.2

Copeland and McDonald. 1985. Principles of seed science and technology. Second Edition. Burgess Publishing Company. United States of America.

Conard, H.S. 1905. The water lilies: A monograph of the genus Nymphaea. Publ. Carnegie Inst. Wash 4:1-279 
Cronk, J.K. and M.S. Fennessy. 2001. Wetland plants. Biology and ecology. CRC Press. United States of America

Dalziell, E.L. 2016. Seed biology and ex situ storage behavior of Australian Nymphaea (Water lilies): Implications for conservation. Thesis. The University of Western Australia.

Daffadil, E.D. and V.R. Mohan. 2013. Total phenolics. flafanoids and in vitro antioxidant activity of Nymphaea pubescens Willd. rhizome. World Journal of pharmacy and pharmaceutical Scinces. (2):37103722

Deka, N. and N. Devi. 1915. Wild edible aquatic and marshland angiosperms of Baksa distric, BTC area, Assam India. Asian Journal of Plants Science and Research. 5(1):32-48.

Deska, J., K. Jankowski, A.Bombik, and J. Jankowska. 2011. Effect of growing medium $\mathrm{pH}$ on germination and initial development of some grassland plants. Acta Sci. Pol., Agriculture. 10(4):45-56.

Fitrial, Y. dan R. Khairina. 2011. Teratai: Aspek gizi, potensi dan pemanfaatannya sebagai pangan fungsional. Eja Publisher. Yogyakarta.

Fitrial Y., M. Astawan, S.S. Soekarto, KG. Wiryawan, T. Wrediyan dan R. Khairina. 2008. Aktivitas anti bakteri ekstrak biji tertai (Nymphaea pubescens Willd.) terhadap bakteri pathogen penyebab diare. J. Teknologi dan industri pangan. XIX (2):158-164.
Guruge D.P.G.S.K., D. Yakandawala and K. Yakandawala. 2016. Confirming the identity of newly recorded Nymphaea rubra Roxb. Ex andrews discerning from Nymphaea pubescens Willd. Using morphometrics and molecular sequence analyses. Bangladesh J. Plant Taxon. 23(2):107-117

Hemalatha, P. and Ilavarasan. 2016. Anti diabetic activity of Siddha herbal preparation allipoo chooranam (Nymphaea pubescens flower) on STZ in duced diabetic Rats. Ijppr.human journal 7(2):283-291.

Issac, J. 1987. Bush Food: Aboriginal food and herbal ethnobotany. Deep publication, New Delhi

Jain, SK. 1991. Dictionary of indian folk medicine an ethnobotany. Deep publication. New Delhi

Krismawati, A. dan M. Sabran. 2003. Eksplorasi buah-buahan spesifik Kalimantan Tengah. Buletin Plasma Nutfah. Vol. 9 No.1 Th. 2003

Kai, L.Z, G.N.H. Peng, G.M. Min and L.T.Y. Ken. 2012. Investigating the effect of soil $\mathrm{pH}$ on the germination of Avicennia alba seedlings. Little Green Dot Student Research Grant PROJECT REPORT.

Katriyayini, T., N.R., Sandu and K.L. Senthilkumar. 2011. Anti diabetic activity on the flower of Nymphaea pubescens Willd. Research Journal of Pharmaceutical, Biological dan Chemical. 2(1):866-873

Kattenring, K. M, G. Gardner and S. M. Galatowitsch. 2006. Effect of light on seed germination of eight wetlans 
Carex Species. Annals of Botany 98:869-874

Khairina, R., dan G. Rusmayadi. 2012. Pendugaan produksi biji teratai (Nhymphaea pubescens Willd.) di perairan rawa lebak Kalimantan Selatan dengan pendekatan metode wagenigen dan melalui pedagang pengumpul biji teratai. Pusat Dokumentasi dan Informasi IlmiahLIPI

Mendez, R.M. and A.R. Miranda. 2015, Studies on the allelopathic effect of aquatic invasive plants on Cicer arietinum L. The International Journal of Engineering and Science. (4):42-48

Mohan, MRMK., N.K. Sethiya dan S.H. Mishra. 2010. A. Comprehensive review on Nymphaea Stellata: A Traditionally used bitter. Jornal of Advanced Phaemaceutical Technology and Research. 1(3):311319.

Muthulingam, M. 2011. Antihepatotoxic efficacy of Nymphaea pubescens (Willd) on acetaminophen induced liver damage in male wistar rats International Journal of Current Research. Vol 3 (012-016). http://www.journalcra.com

Nugroho, T. 2011. Pengaruh derajat keasaman terhadap perkecambahan biji.

http://trias-nugrohobioq.blogspot.com/2011/11/pengaruh -derajat-keasaman- terhadap.html

Orozco-Orbando W. Tilk K, and B. Fischman. 2009. Cultivation of lotus (Nelumbo nucifera and Nelumbo lutea) advances in soil and fertility management. Water Garden Journal $24(1): 9$

Rahangdale D., and S.S. Rahangdale, 2013. Potential wild edible plant resources from Maharashtra futures prospects for their conservation and improvement. http://lifescienceiflets.ning.com/

Roy, D.K., A.D. Talukdar, MD. Choudhury and BK. Sinha. 2013. Less known uses of Nymphaea spp. (Nymphaeaceae) as the traditional food I tem (Vhet-Laddu) in northeast india. International Journal of Food Agriculture and Veterinary Sciences. $3(2): 82-87$.

Rokaya and Münzbergová. 2012. Effect of light, temperature and seed mass on germination of two species of the Himalayan Rhubarb. Journal of Medicinal Plants Research. 6(37):032-5037.

http://www.academicjournals.org/JM PR DOI: $10.5897 / J M P R 11.1419$

Selvakumari, E., S. Shantha, P.T. Purushath and S. Kumar. 2012. Antiproliferative activity of ethanolic flower extract from Nymphaea pubescens Willd. Extract from Nymphaea pubescens Willd. Against human cervical and breast carcinoma in vitro. International Research journal of Pharmacy. 3(1):124-125

Sumlu, S., H. H. Atar, and K. M. Khawar. 2010. Breaking seed dormancy of Water Lily (Nymphaea alba L.) under in vitro conditions. Biotechnol and Biotechno. 24(1):1582-1586.

Subagyo, H. 2006. Klasifikasi dan penyebaran lahan rawa. Balai Besar Penelitian dan Pengembangan Sumberdaya Lahan Pertanian, Badan 
Penelitian dan Pengembangan Pertanian, Departemen Pertanian

Sutopo, L. 1993. Teknologi Benih. Rajawali Pres. Jakarta

Swingle, D. B. 1956. A Textbook of Systematic Botany. McGRAW-HILL BOOK COMPANY, INC. New York and London.

Tohari, D.Shiddieq dan P.Sudira. 2018. Asepek Dasar Agronomi Berkelanjutan. Gadjah Mada University Press.
Webb, M.A., R.A. Ott, Jr., and C.C. Bonds. 2012. Propagation and establishment of native aquatic plants in reservoirs

Wiersema, J.H. 1987. A monograph of Nymphaea subgenus Hydrocallis (Nymphaeaceae). Systematic Botany Monographs. 16:1-112

Zhu, M., X. Zheng, Q. hu, H. Li, P Zhong, H. Zhang, Y. Xu, L. Wang, and L.Wang. 2012. Relationship between the composition of flavonoids and flower colors variation in tropical Water Lilly (Nymphaea) cultivars. Open acces plos one. 2:1-11. 